\title{
A review on the legislative aspect of artificial fruit ripening
}

\author{
Md. Nazibul Islam, Mehnaz Mursalat and Mohidus Samad Khan*
}

\begin{abstract}
Fruit ripening is a natural process in which a fruit goes through various physical and chemical changes and gradually becomes sweet, colored, soft, and palatable. Fruit ripening process can also be stimulated by applying artificial fruit ripening agents. Farmers and vendors often use artificial ripening agents to control the rate of fruit ripening. However, because of the potential health hazards related to the ripening agents, artificial fruit ripening process is highly debatable throughout the world. There are existing laws and guidelines to control artificial fruit ripening process. This article highlights the legal aspects of artificial fruit ripening and fruit adulteration throughout the world. Different laws and acts of both the developed and developing countries to control and prohibit artificial fruit ripening and adulteration using hazardous chemicals are discussed here. The technical and economic issues related to artificial fruit ripening are also addressed in this study. This article aims at developing awareness among government agencies, policymakers, farmers, vendors, and scientists, as since it will take collective participation of different stakeholders to address different aspects of artificial fruit ripening issues and to provide an effective solution.
\end{abstract}

Keywords: Artificial fruit ripening, Legislations, Supply chain, Economic impact, Law synchronization

\section{Background}

Different fruit ripening agents can be used to ripen fruits artificially and to provide fruits the desired color and taste within a short time. In recent years, the use of artificial fruit ripening agents is becoming much prevalent, the agents being mostly used for commercial purposes, i.e., to make the fruits available to customers during off-season. Recent reports on fruit ripening agents highlight health issues [1-7] pertaining to artificial fruit ripening agents. Agents such as calcium carbide, ethephon, and ethylene have been reported to be used as artificial ripening agents. Whether these agents pose any threat to human health or on the surroundings has become a global concern, which needs to be addressed. Recent reports on the possible health hazards associated with artificial fruit ripening and artificial fruit ripening agents strengthen the need for further study on the issue $[1,5-7]$.

Many countries have specific laws and regulations regarding the usage of these substances [5, 8-17].

*Correspondence: mohid@che.buet.ac.bd

Department of Chemical Engineering, Bangladesh University

of Engineering and Technology (BUET), Dhaka 1000, Bangladesh
Although the terms and conditions of the corresponding legislations vary from country to country, the major objective to enact such laws is to control or prohibit the usage of the chemicals as ripening agents.

There are different economic and technological factors related to the artificial fruit ripening issues $[1,5,7$, 17-19]. Along with providing legislative guidelines, technologically developed nations are also providing technological assistance to the farmers and vendors to produce and supply ripe fruits that are safe for human health $[1$, $12,14,17,20]$.

The prime objective of this article is to report and discuss the legal status of artificial fruit ripening around the world: developed and developing countries. The article also aims to compare and analyze the existing policies and regulations regarding artificial fruit ripening to find out the best possible solution.

\section{Artificial fruit ripening \\ Mechanism of natural fruit ripening}

Natural fruit ripening is a combination of physiological, biochemical, and molecular processes [21-24]. It involves coordination of different metabolisms with 
activation and deactivation of various genes, which leads to changes in color, sugar content, acidity, texture, and aroma volatiles $[21,22,25]$. The change in color during the fruit ripening process is a result of unmasking of pigments by degradation of chlorophyll, synthesis of different types of anthocyanins and their accumulation in vacuoles, and accumulation of carotenoids. Production of complex mixture of volatile compounds, such as ocimene and myrcene, and degradation of bitter principles (diverse groups of plant constituents such as alkaloid and sesquiterpene are linked only by their bitter taste), flavonoids, tannins, and other related compounds enhance the flavor and aroma of the fruit. Sweetness increases because of increased gluconeogenesis (metabolic pathway that generates glucose), hydrolysis of polysaccharides, decreased acidity, and accumulation of sugars and organic acids. Furthermore, textural changes resulting in the softening of fruits occur due to enzyme-mitigated alteration in structure and composition of the cell wall $[23,26,27]$. Through the above changes, fruit becomes ripe with distinctive characteristics: sweet, colored, soft, and palatable.

\section{Artificial fruit ripening and possible health hazards}

Ethylene, a hormone naturally produced within fruit, regulates fruit ripening by initiating and/or controlling a series of chemical and biochemical activities [28]; the compound does so by coordinating the genes responsible for activities including increase in the rate of respiration, autocatalytic ethylene production, chlorophyll degradation, carotenoid synthesis alongside conversion of starch to sugar, increased activity of cell-wall-degrading enzymes, color change, texture, aroma, and flavor of the fruit $[29,30]$. Chemicals such as chemically synthesized ethylene, methyl jasmonate, calcium carbide, ethephon, and ethylene glycol can also be used to replicate this process artificially $[1,5,7,18]$.

Among the widely used artificial ripening agents, ethylene and methyl jasmonate are reported as non-toxic for human consumption; however, they are relatively expensive [1]. In many developing countries, low-cost chemicals such as calcium carbide [1, 5], ethylene glycol [7], and ethephon [18] are reported to be commonly used to artificially trigger the ripening process.

Upon application on fruits, calcium carbide comes into contact with moisture and releases acetylene gas, which has fruit ripening characteristics similar to ethylene [1]. On the other hand, in the presence of moisture and at neutral $\mathrm{pH}$, ethephon is decomposed into ethylene gas, biphosphate ion, and chloride ion [31]. Individually, these chemicals can have adverse effects on human health [1, 5-7]. Direct consumption of acetylene has been found to reduce oxygen supply to the brain and can further cause prolonged hypoxia [6]. Calcium carbide is alkaline in nature and irritates the mucosal tissue in the abdominal region; cases of stomach disorder after eating carbideripened mangoes have also been reported [5]. Because of the presence of impurities such as arsenic and phosphorus found in industrial grade calcium carbide, workers applying calcium carbide on fruits are likely to encounter serious health threats-dizziness, frequent thirst, irritation in mouth and nose, weakness, permanent skin damage difficulty in swallowing, vomiting, skin ulcer, and so forth [5]. A generous consumption of ethylene glycol may cause kidney failure [7]. Table 1 lists commonly used artificial ripening agents and their possible effects on human health.

\section{Legal status: South Asian countries}

The South Asian Association for Regional Co-operation (SAARC) includes Afghanistan, Bangladesh, Bhutan, India, Maldives, Nepal, Pakistan, and Sri Lanka. No unified policy on fruit cultivation, preservation, and distribution exists within these countries. As artificial fruit ripening using calcium carbide poses greater threat to human health, most of the SAARC countries have banned the use of calcium carbide as an artificial fruit ripening agent $[5,11,13,16,33]$.

In India, the use of carbide gas for fruit ripening is prohibited under Rule 44 AA of the Prevention of Food Adulteration Rules 1955 [34]. Moreover, the Food Safety and Standards Regulations, 2011, explicitly prohibits the selling of fruits, which are artificially ripened by carbide gas [11]. In addition, selling unsafe food is punishable under Sects. 50 and 59 of Food Safety and Standards Act, 2006 [35].

In Bangladesh, the laws and acts on fruit ripening and marketing include Bangladesh Pure Food Ordinance (Amendment) Act 2005 that originated from the Bangladesh Pure Food Ordinance, 1959, Agricultural products Market Act 1950 (revised in 1985), The Bangladesh Standards and Testing Institution Act, 1985, The Plant Quarantine Act 2011, The Mobil Court Act 2009, Bangladesh Consumer Protection Act 2009, and The penal code of Bangladesh, Formalin Control Act 2014 [36]. According to the Bangladesh Pure Food Ordinance (Amendment) Act 2005, a new section. 4A, has been introduced that proposes the formation of a National Food Safety Advisory Council (NFSAC), which will advise the Government regarding food safety. Section $6 \mathrm{~A}$ of the ordinance prohibits the sale of any food in which chemicals such as calcium carbide, formalin, pesticides (DDT, PCBs oil, etc.) have been used [13]. The Mobile Court Act 2009 gives magistrates the authority to impose maximum sentence of 2 years to anyone who is found guilty of illegal usage of artificial fruit ripening agents [37], and to penalize the person right on the spot. 
Table 1 List of commonly used chemicals for fruit ripening and their effects on human health [1, 5-7, 32]

\begin{tabular}{lc}
\hline Name and chemical structure & Possible health effect \\
\hline Calcium carbide $\left(\mathrm{CaC}_{2}\right)$ & $\begin{array}{c}\text { Direct consumption of acetylene gas released by calcium carbide can reduce oxygen supply to the } \\
\text { brain and can cause prolonged hypoxia }\end{array}$ \\
& Calcium carbide in general is alkaline in nature and can cause irritation in the mucosal tissue in the \\
& abdominal region \\
& Arsenic and phosphorous found in industrial grade calcium carbide can cause dizziness, frequent \\
& thirst, irritation in mouth and nose, weakness, permanent skin damage difficulty in swallowing, \\
vomiting, skin ulcer, etc & Direct consumption of ethylene glycol may cause kidney failure \\
Ethylene glycol $\left(\mathrm{C}_{2} \mathrm{H}_{5} \mathrm{O}_{2}\right)$ & Comparing to calcium carbide and ethylene glycol, ethylene and methyl jasmonate are less (or \\
jasmonatene $\left(\mathrm{C}_{2} \mathrm{H}_{4}\right)$ and methyl $\left(\mathrm{C}_{13} \mathrm{H}_{20} \mathrm{O}_{3}\right)$ & no reported adverse effect on human heath for limited concentration (maximum residue limit: \\
Ethephon $\left(\mathrm{C}_{2} \mathrm{H}_{6} \mathrm{ClO}_{3} \mathrm{P}\right)$ & 1 pmm to 50pmm depending on fruits) \\
\hline
\end{tabular}

The food laws in Pakistan are similar to those in Bangladesh. In Pakistan, the primary law related to food is the 'West Pakistan Pure Food Ordinance, 1960' [38], which is to some extent similar to the East Pakistan Pure Food Ordinance, 1959, now amended as Bangladesh Pure Food Ordinance (Amendment) Act 2005. Section 6 of this law deals with adulterated food items and is applicable throughout Pakistan (except the cantonments) with minor regional changes. Like Bangladesh, the cantonment areas in Pakistan are governed by Cantonment Pure Foods Act 1966 [39]. The offenses under these acts are classified as first offense, second offense, and repeated, large, or serious offense. The punishments include fine and/or imprisonment [39].

In Sri Lanka, under the Food Act No 26 of 1980, no person can manufacture, sell, or distribute food that has any natural deleterious substance added upon it which are injurious to health [15].

In Nepal, Part 7, rule no 19(d) of The Nepal Food Regulation 2027 strongly prohibits the use of carbide gas in fruit ripening $[5,16]$.

Table 2 summarizes the major laws and acts on artificial fruit ripening that are practiced in the SAARC countries.

\section{South Asian Regional Standards Organization (SARSO)}

Headquartered in Dhaka, Bangladesh, South Asian Regional Standards Organization is responsible for harmonizing national standards of SAARC member states and for developing SAARC standards on common products of interest [41-43]. To date, the organization has identified 28 common products for harmonization of standards; however, fruit and fruit-related products are not on the list [42]. SARSO can be used as a platform for issuing a single list of artificial fruit ripening agents that should be banned in the whole South Asia region.

\section{Country focus: Bangladesh}

With a growing economy, Bangladesh is one of the key members of SAARC. In Bangladesh, government ministries and agencies responsible for the inspection, examination, and control of ripening, harvesting, and marketing activities of fresh fruit include [44]:

- Ministry of Agriculture-plant protection wing

- Customs-inspection of imported fruits and vegetables

- Mobile court

- Ministry of Health-sample collection and testing

- Ministry of Science-pesticide testing

Several laws, regulations, and standards exist to support the activities of the above-mentioned agencies in order to maintain the quality of home-grown and imported fruits [44-46]. The relevant laws and acts are as follows:

- Bangladesh Pure Food Ordinance (Amendment) Act 2005

- Agricultural products Market Act 1950 (revised in 1985) and The Bangladesh Standards and Testing Institution Act 1985

- The Plant Quarantine Act 2011

- The Mobile Court Act 2009

- Bangladesh Consumer Protection Act 2009

- The Penal Code of Bangladesh

- Formalin Control Act 2014

Bangladesh Pure Food Ordinance (Amendment) Act 2005 bans the use of calcium carbide, formalin, and pesticides [such as dichlorodiphenyltrichloroethane (DDT) and polychlorinated biphenyls (PCBs)] [13]. The Bangladesh Standards and Testing Institution Act 1985 relates 
Table 2 Laws and regulations practiced in the SAARC countries to prohibit artificial fruit ripening and food adulteration [40]

\begin{tabular}{|c|c|c|}
\hline Country & Laws and regulations & Aims and actions \\
\hline \multirow[t]{7}{*}{ Bangladesh } & Bangladesh Pure Food Ordinance (Amendment) Act 2005 & $\begin{array}{l}\text { Formation of National Food Safety Advisory Council (NFSAC); prohibit } \\
\text { using calcium carbide, formalin, and pesticides in foods }\end{array}$ \\
\hline & $\begin{array}{l}\text { Agricultural products Market Act, } 1950 \text { (revised in 1985) and } \\
\text { The Bangladesh Standards and Testing Institution Act } 1985\end{array}$ & $\begin{array}{l}\text { To empower Bangladesh Standards and Testing Institution (BSTI) surveil- } \\
\text { lance teams for field test and monitoring }\end{array}$ \\
\hline & The Plant Quarantine Act 2011 & To prevent unapproved import and export of plants \\
\hline & The Mobil Court Act 2009 & To empower the magistrates of mobile courts \\
\hline & Bangladesh Consumer Protection Act 2009 & To prohibit using any substance in food that is harmful for human health \\
\hline & Formalin Control Act 2014 & To control the use of Formalin \\
\hline & The penal code of Bangladesh & To penalize any individual selling illegally ripened fruits \\
\hline \multirow[t]{3}{*}{ India } & Prevention of Food Adulteration Rules 1955 & To prohibit the use of carbide gas for fruit ripening \\
\hline & Food Safety and Standards Act 2006 & \\
\hline & Food Safety and Standards Regulations 2011 & Prohibiting the selling artificially ripened fruits using carbide gas \\
\hline \multirow[t]{2}{*}{ Pakistan } & West Pakistan Pure Food Ordinance, 1960 & To address and limit food adulteration \\
\hline & Cantonment Pure Foods Act 1966 & To address and limit food adulteration at the Cantonment areas \\
\hline Nepal & The Nepal Food Regulation 2027 & To prohibit the use of carbide gas for fruit ripening \\
\hline Sri Lanka & Food Act No 26 of 1980 & $\begin{array}{l}\text { To prohibit manufacturing, selling, and distributing of any adulterated } \\
\text { food }\end{array}$ \\
\hline
\end{tabular}

to the establishment of BSTI [47]. This ordinance has been amended as The Bangladesh Standards and Testing Institution (Amendment) Act 2003. Under the act, products are collected by the BSTI surveillance team directly from the open market and later tested in the BSTI laboratories. The Plant Quarantine Act 2011 prohibits unapproved export and import of plants, as well as parts of plants [48]. Violation of this law may result in maximum 2 years of imprisonment or a fine of BDT 500,000 (USD $\$ 6,250$ approximately), or both. The Mobile Court Act 2009 empowers magistrates to penalize any individual selling artificially ripened fruits, on spot [37]. In addition to these, there exists other laws and acts, which ban the use of harmful substances in the production, preservation, and marketing of fruits: Bangladesh Consumer Protection Act 2009 [49], the Penal Code of Bangladesh [50], and Formalin Control Act 2014 [45, 46].

A flowchart on the available policies, laws and regulations, and testing facilities to control and prohibit artificial fruit ripening in Bangladesh is shown in Fig. 1.

\section{Legal status: East Asian countries}

In Malaysia, 'The Food Act 1983' governs the legislative aspects of food and food-related activities. The law strictly prohibits the use of any substance that may deteriorate the nutritive and/or other beneficial properties of food. The law further prohibits the use and sale of foods containing substances that are injurious to health [51]. Since artificial fruit ripening agents such as calcium carbide and ethylene glycol are harmful for human health [1, 5-7]; therefore, according to 'The Food Act 1983' using those substances for artificial fruit ripening can be considered unlawful in Malaysia.

In Indonesia and Thailand, there are general laws concerning food; however, there is no specific regulation to control artificial fruit ripening issues. The food industry of Indonesia is governed by the 'Act Number 7 of 1996, where chapter II of this act deals with food safety [52]. The chapter is further divided into several articles, which deal with the different aspects of food safety, for example proper sanitation, prohibition of use of food additives injurious to human health, and more [53]. The food industry in Thailand is governed by the 'Food Act 1979.' The objective of this act is to protect consumers from hazards arising from food consumption [52]. Thus, these regulations can be used to regulate the hazardous ripening agents in Indonesia and Thailand, respectively.

In China, the overall food safety is governed by the 'Food Safety Law of the People's Republic of China.' This law covers the standards, inspection, supervision and administration, and legal liabilities concerning food safety. According to this law, production or distribution of food or food additives containing contaminants and heavy metals above the safety standard limit is punishable by a fine of RMB 10,000-100,000, and/or revoking of license depending on the extent of the offense [54]. Additionally, 'Food Hygiene Law of the People's Republic of China,' 'Regulation on Managing Hygiene in Food Additives', and 'Law on Agricultural Product Quality' aim to prevent food contamination and use of food additives that are harmful to human health [55]. 


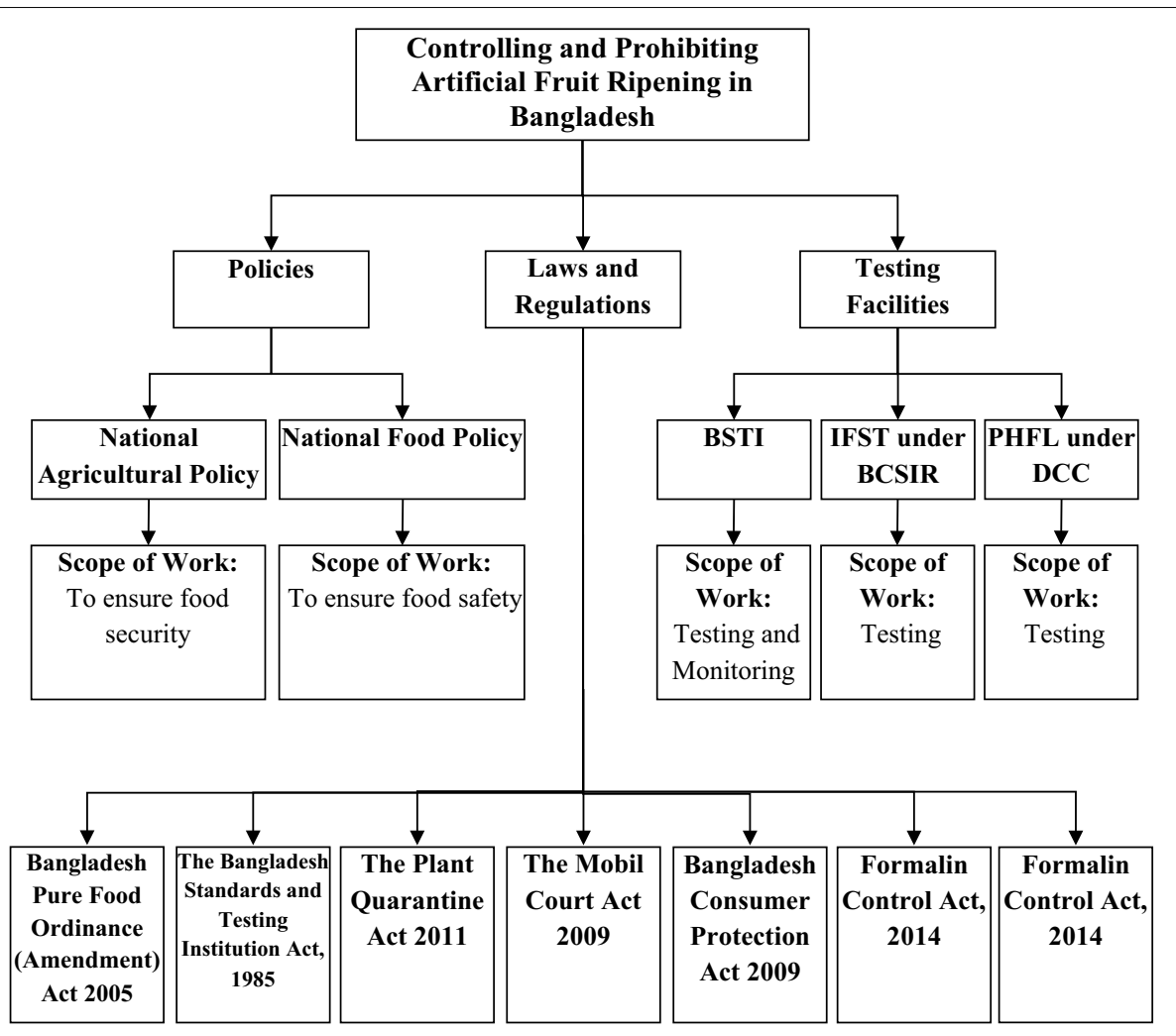

Fig. 1 Controlling and prohibiting artificial fruit ripening in Bangladesh [40]

\section{Legal status: Gulf Co-operation Council (GCC)}

Bahrain, Iran, Iraq, Kuwait, Oman, Qatar, Saudi Arabia, and the United Arab Emirates are the eight nations that together share the coast of Persian Gulf. Among them, Bahrain, Kuwait, Oman, Qatar, Saudi Arabia, and the United Arab Emirates form the Gulf Co-operation Council (GCC), which mostly import fresh fruits from other countries [56]. As a result, the GCC countries set regulations targeting the fruit exporting countries. In order to export fruits to the GCC countries, fruit producers and exporters must comply with the regulations set by the GCC countries.

The aim of GCC is to promote coordination between member states in order to achieve unity. One of the many primary objectives of this council is to foster scientific and technical progress in agricultural and food industries [57]. The Gulf Standards Organization (GSO), comprising of the six GCC countries and Yemen, is responsible for the development of food standards. However, differences still prevail among some of the proposed new standards and existing international guidelines. So far, approximately 1000 food-related legislations and standards have been developed by GSO [58].

The GSO consists of three subcommittees for foodrelated issues [58]:
1. Biotechnology and Organic Food Subcommittee (presided by UAE)

2. Labeling Subcommittee (presided by Oman)

3. Additives Subcommittee (presided by Saudi Arabia)

The standard no. GSO 2401:2014 under GSO Food Standard Act implies that pineapple belonging to the Bromeliaceae family should be supplied fresh to the consumers upon preparation and packaging [59]. The GSO Food Standards Committee, presided by Qatar, has been playing a key role in harmonizing existing GCC standards within the guidelines of the Codex Alimentarius, ISO, and other international organizations. Majority of the acts follow the Codex Alimentarius [58].

The gulf countries do follow the standards set by the GSO collectively, yet some of the countries have imposed additional acts that fall under the national acts for food safety. For example, Qatar imposed a set of regulations on food quality investigation [60]:

- All newly processed food products arriving in the market are subjected to laboratory analysis

- Subsequent shipments of a product that has passed the initial testing will be subject to further laboratory analysis again after 6 months 
- A product failing a previous inspection will be thoroughly examined on subsequent shipments for an undisclosed length of time.

\section{Legal status: African countries}

In Africa, calcium carbide is widely used as an artificial fruit ripening agent $[1,3-5,61]$. Recently, there is an upsurge in reported cases of carbide-ripened fruits seized in Kenya and Nigeria [2-4]. Like South Asia, the calcium carbide used in these countries is of low quality [1], and poses threat to human health [5]. Although regulatory bodies exist to deal with food safety, however, there is still lack of specific regulations and technical support to control artificial fruit ripening in a good number of African countries $[3,4,62]$.

The East African Community (EAC) is a regional economic community comprising of Kenya, Uganda, Tanzania, Burundi, and Rwanda. The EAC has a catalog of East African Standards, which enlists the standard testing methods for fruits and its derivatives [63]. Although this catalog does not address the use of artificial fruit ripening agents, the EAC countries, however, can add a list of banned ripening agents so that there is a single regulation that can address artificial fruit ripening within the region.

The FAO/WHO Regional Conference on Food Safety for Africa (2005) lists the food safety regulations of 53 African courtiers [64]. These regulations cover a wide range of products such as meat and meat products, milk, and cereals. In general, there are no specific regulations for fruit and fruit-related products; however, a notable exception is the Fruit Marketing Act (No. 55 of 1966), Zimbabwe. Among the 53 countries, only 34 have defined food standards, inspection mechanism, and laboratory support system. Recently, there has been significant improvement in food safety systems in countries such as Benin, Burkina Faso, Gabon, Mali, and Zimbabwe [65].

\section{Country focus: Nigeria}

Nigeria is a mixed economy emerging market in Africa. In Nigeria, the following governmental ministries and agencies are responsible for developing and maintaining food safety standards and practices $[8,9]$ :

- National Agency for Food and Drug Administration and Control (NAFDAC)

- Standards Organization of Nigeria (SON)

- Federal Ministry of Health

- National Codex Committee

- Federal Ministry of Agriculture

- Consumer Protection Council

- States and Local governments.
These organizations are supported by several laws and regulations that ensure food safety in Nigeria. These laws include: Standards Organization of Nigeria (SON) Decree No. 56 (1971), Food and Drugs Decree No 35 (1974), Consumer Protection Council Decree No. 66 (1992), National Agency for Food and Drugs Administration and Control (NAFDAC) Decree No. 15 (1999), The National Agency for Food and Drugs Administration and Control (NAFDAC) Act Cap N1 LFN (2004) and Act Cap F32 LFN (2004) [8, $9,66,67]$.

The Standards Organization of Nigeria (SON) is a member of Codex Alimentarius Commission, which was establised by FAO and the World Health Organization to develop harmonised food standards [68]. This implies that SON follows the permissible list of fruit additives by Codex Alimentarius Commission and the list of codes on fresh and processed fruits. These codes are as follows [69]:

- Code of hygienic practice for canned fruit and vegetable products

- Code of hygienic practice for dried fruits

- Code of hygienic practice for dehydrated fruits and vegetables including edible fungi

- Code of practice for the packaging and transport of fresh fruit and vegetables

- Code of hygienic practice for fresh fruits and vegetables.

National Agency for Food and Drugs Administration and Control (NAFDAC) is the regulatory body that regulates and controls the import, export, manufacture, advertisement, distribution, sales, and use of food and other regulated products $[9,66,67]$. The agency has the authority to inspect, investigate, and test food items in the market in order to ensure safety [67].

Consumer Protection Council Decree No. 66 (1992) establishes the Consumer Protection Council. It is the responsibility of the council to seek ways and means to remove and eliminate hazardous products from the market, to publish list(s) of prohibited products, and to create awareness among consumers [70]. Therefore, preparing a list of chemical preservatives, additives, and fruit ripening agents, which are harmful for human health, falls within the work scope of the Consumer Protection Council of Nigeria.

Figure 2 shows the major policies, laws, and regulations available to control and prohibit artificial fruit ripening in Nigeria.

\section{Legal status: western countries}

In different Western countries, selected ripening agents are allowed to be applied to ripen specific fruits under controlled condition. In this process, ethylene is injected 


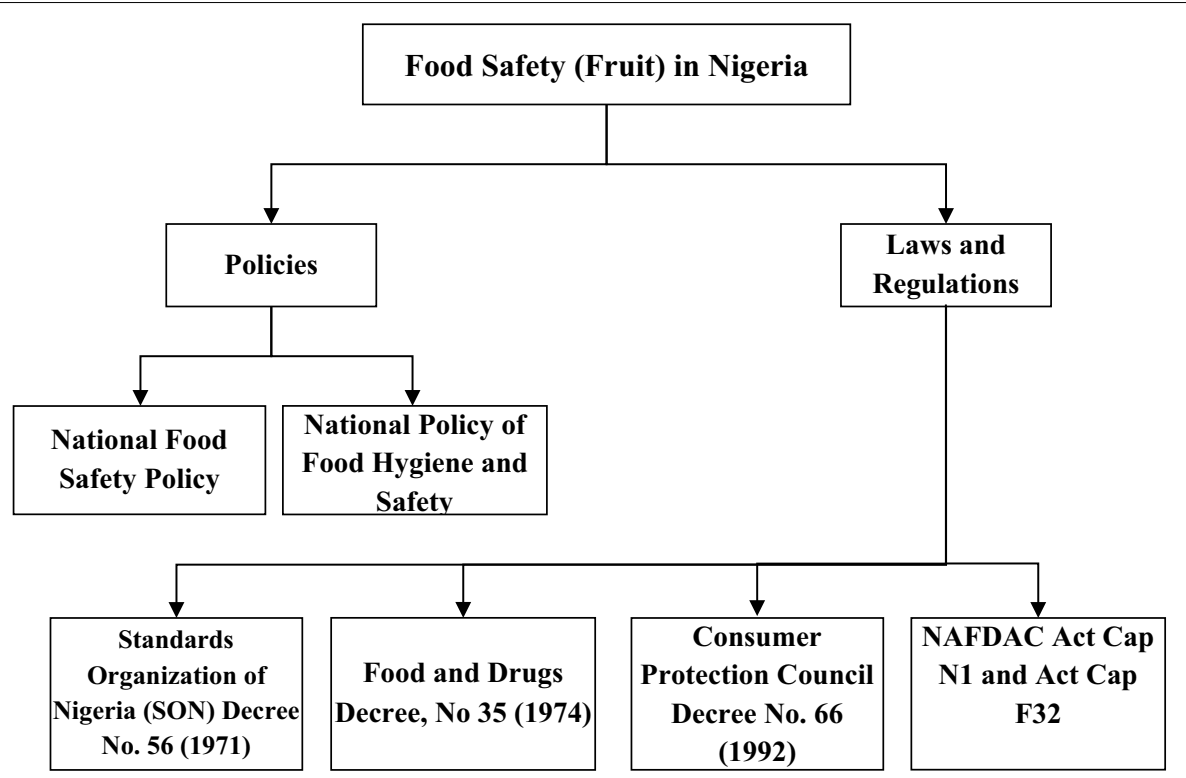

Fig. 2 Controlling and prohibiting artificial fruit ripening in Nigeria

to the fruit ripening chambers in a controlled manner, to help instigating the ripening process [1].

\section{North America}

In USA, the United States' NOSB [National Organic Standard Board] recommends the use of ethylene for post-harvest ripening of tropical fruits and de-greening of citrus; this is stated in the 'Formal Recommendation by the National Organic Standard Board (NOSB) to the Organic Program (NOP)' [17]. The United States Environmental Protection Agency (EPA) allows the use of ethylene as plant growth regulator and herbicide. Additionally, ethylene is exempt from the requirement of a tolerance (maximum residue level) when used as a growth regulator on fruits and vegetables [71].

The regulations set by the Canadian Food Inspection Agency (CFIA) imposes that no person shall market, produce, import, export, or take part in interprovincial trade of fruits and vegetables unless it is not contaminated, edible, free of any live insect or other living thing that may be injurious to health, and produced hygienically [12]. CFIA gives more emphasis on ensuring the quality of water used in food and vegetable processing; the following features are suggested to ensure production under hygienic conditions:

- No stagnant or polluted water should be used in the washing or fluming of the produce;

- Only potable water is to be used in the final rinsing of the produce to remove any surface contaminant before packing;
- The final rinse water, if reused, is used only in the initial washing or fluming of the product.

\section{Europe}

United Kingdom's Soil Association permits the use of ethylene to ripen bananas and kiwi [Soil Association Organic Standards, rev 16.4, June 2011] [19]. The UK Food Safety Act enacted in 1990 imposes that any person who renders any food injurious to health by means of any of the operations-adding any article or substance to the food, using any article or substance as an ingredient in the preparation of the food, abstracting any constituent from the food, and subjecting the food to any other process or treatment with intent that it shall be sold for human consumption, shall be guilty of an offense [14].

The European Food Safety Authority (EFSA) under the regulation (EC) No 396/2005 developed the Standard Sample Description (SSD), which is a standardized model for the reporting of harmonized data on analytical measurements of chemical substances present in food, feed, and water [72]. As an attempt to make significant reforms of the Common Market Organization (CMO) for certain agricultural products, the European Union extended its approach to the promotion, quality, and marketing standards for fresh and processed fruit and vegetables. Provisions for a management committee that apply to the fruit and vegetable sector as well as a range of other agricultural products came into effect from January 1, 2008, under Council Regulation (EC) No. 1234/2007. Key objectives of the regulation are as follows [73]: 
- Planning of production;

- Improvement of product quality;

- Boosting products' commercial value;

- Promotion of products, whether in a fresh or processed form;

- Environmental measures and methods of production respecting the environment, including organic farming;

- Crisis prevention and management.

\section{Other international organizations}

Evidently, the laws in different developed countries do not completely prohibit using artificial ripening agents, and often permit the control use of ethylene gas for artificial fruit ripening. The International Federation of Organic Agriculture Movements' (IFOAM) enlists ethylene gas as 'Only for ripening fruits' in the IFOAM Indicative List of Substances for Organic Production and Processing. Similarly, the Asia Regional Organic Standard (AROS) developed by Global Organic Market Access (GOMA) (a project of FAO), IFOAM, and UNCTAD (United Nations Conference on Trade and Development) permit the usage of ethylene for the ripening of kiwifruit, bananas, and other tropical fruits [74].

\section{Law synchronization for developing countries: supply chain, economic impact, and technological development}

In most of the developing countries, farmers often use artificial ripening agents to sell fruits during offseason; they also use ripening agents to meet the growing demands during the actual ripening season. Another important issue, especially in the developing world, to address is the complex supply chain. For example, in the fiscal year 2006-2007 Bangladesh produced around 2.74 million metric tons of fruits [75]. In Bangladesh, distributing fruits from the farmers' orchards to consumers' baskets can take several days. During distribution, fruits are collected from farmers and sent to the local storage points. From local storages (or collection points), fruits are transported to the warehouses of major cities and remote areas of the country, from where the retailers collect the fruits and sell them to customers. During this time, naturally ripened fruit may become overripe, and therefore become inedible. In addition, the unavailability of sufficient storage facility can also make fruits unfit for sale, leading to an economic loss for the fruit sellers. Hence, to minimize this loss, fruit sellers sometimes prefer collecting fruits before they are fully ripe, and artificially ripen the fruits before selling them to the consumers.

However, new technological developments can offer safer and economically viable means to artificially ripen fruits. For instance, a mixture of ethephon and sodium hydroxide in water, or diluted ethylene glycol solution can be used as artificial ripening agents without causing significant harmful effects on human health $[1,5,7]$.

For mass production, ethylene ripening chambers can serve as a promising option. Specially designed chambers are already in use in the developed countries to artificially ripen fruits [4]. Recently, India is in the process of utilizing the ripening chambers and has already formalized technical standards and protocol for fruit ripening chambers [76]. Other developing countries can also take similar initiatives to modernize fruit ripening processes on a commercial scale. Small and rural farmers can utilize ethereal or glycol solution or set up ripening chambers on a cooperative basis. A fully computerized single ripening chamber of volume $57 \mathrm{~m}^{3}(5.07 \mathrm{~m} \times 3.31 \mathrm{~m} \times 3.39 \mathrm{~m})$ may cost approximately USD\$20,000 [77]. However, cheaper manpower and extensive experience in this field can lower the operational cost [78].

\section{General comments}

The key factors that influence the practice of artificial fruit ripening include high demand of seasonal fruits, and possible economic loss during fruit storage and distribution. In most of the developing countries, chemicalinduced artificial fruit ripening is limited or prohibited by law in order to ensure health safety. On the other hand, the developed countries have mitigated these issues through efficient supply chain, and by following standard procedures of fruit ripening. From an economic point of view, as long as there is a high demand for seasonal fruits, or chances of loss of ripen fruits during storage and distribution, the producers and/or merchants will be inclined toward using artificial fruit ripening agents. For example, fruits ripened with $39 \%$ ethephon, commercially known as ethereal, have more acceptable color than naturally ripened fruits and have higher shelf-life than carbide-ripened fruits $[1,5]$. Similarly, $20 \%$ ethylene glycol will ripen various fruits faster in colder climatic condition [7]. For mass production, ethylene ripening chamber may be considered as an alternative. Countries such as India are keen toward utilizing the potential of ripening chambers and have already formalized technical standards and protocol for these chambers [79]. Furthermore, to address the socioeconomic and technical issues of artificial fruit ripening, the governments of developing countries can follow the examples set by the developed countries and may come up with standard fruit ripening techniques. A list of ripening techniques and chemicals with defined permissible limits, and a global standard for ripening chambers can be introduced under the framework of WHO/FAO. Moreover, major locations within the chain of distribution must be identified, and proper 
storage facilities need to be set up at those points so that the ripened or semi-ripened fruits can be stored and distributed according to market demand.

\section{Conclusion}

Artificial fruit ripening is a complex issue, especially for the developing countries, where farmers apply unregulated artificial ripening techniques to satisfy local and international demand. Developing countries such as India, Bangladesh, and other South Asian countries have sufficient legal framework to control artificial fruit ripening. In spite of having strict laws and acts, the inclination toward the use artificial ripening agents is dominant among farmers and the vendors. Therefore, there is a need for the policies, laws, and regulations on artificial fruit ripening to be enforced strictly. Many African countries do not have specific laws to regulate artificial fruit ripening. As a result, most of these countries rely on the international standards on food safety for guidance. Unfortunately, there are no international regulations that manage artificial fruit ripening techniques. Unlike the developing nations, the developed countries have proper guidance for the use of ethylene as ripening agent. These standards can be adopted by other countries or can be used to set up an international standard under the framework of WHO/FAO. Lastly, mass awareness must be raised among farmers, sellers, and consumers regarding artificial fruit ripening and its possible health hazards. Media, lawmakers, researchers, and technology experts can play a vital role in this respect.

\begin{abstract}
Authors' contributions
MNI carried out a major part of the literature review and drafted the manuscript. MM carried out literature review for selected sections and helped to revise the manuscript. MSK conceived the study, supervised the research project, coauthored and supervised manuscript preparation, and helped to finalize the manuscript. All authors read and approved the final manuscript.
\end{abstract}

\section{Acknowledgements}

This research was supported by BCEF Academic Research Fund and BUET CASR Research Grant. The research and manuscript are free of conflict of interest.

\section{Competing interests}

The authors declare that they have no competing interests.

Received: 14 January 2016 Accepted: 13 May 2016

Published online: 20 June 2016

\section{References}

1. Ur-Rahman A, Chowdhury FR, Alam MB. Artificial ripening: what we are eating. J Med. 2008;9(1):42-4.

2. Oche M. Artificial ripening: watch out, that fruit might be dangerous to you, in LEADERSHIP NEWSPAPER. 2014. http://leadership.ng.

3. Koros K. Kenya: sweet poison-illegal ripening of fruits exposes millions of Kenyans to cancer, in Allafrica. 2014. The Star.

4. Board E. NAFDAC and carbide ripened fruits, in PUNCH. 2014. http://www.punchng.com.
5. Siddiqui MW, Dhua RS. Eating artificial ripened fruits is harmful. Curr Sci. 2010;99(12):1664-8.

6. Fattah SA, Ali MY. Carbide ripened fruits—a recent health hazard. Faridpur Med Coll J. 2010;5(2):37.

7. Goonatilake R. Effects of diluted ethylene glycol as a fruit-ripening agent. Glob J Biotechnol Biochem. 2008;3(1):8-13.

8. Nyor JT. The role of regulatory agencies in food quality control in Nigeria. SCSR J Agribus. 2014;1 (1):01-5.

9. Omojokun J. Regulation and enforcement of legislation on food safety in Nigeria. In: Makun HA, editor. Mycotoxin and food safety in developing countries. INTECH Publication; 2013. ISBN 978-953-51-1096-5.

10. FAO, IFOAM, UNCTD. ASIA REGIONAL ORGANIC STANDARD. 2012, United Nations Conference on Trade and Development (UNCTAD), Food and Agriculture Organization of the United Nations (FAO) and International Federation of Organic Agriculture Movements (IFOAM).

11. Food Safety and Standards (Prohibition and Restrictions on Sales) Regulations. Food Safety and Standards Authority of India, Editor. New Delhi:Ministry of Health and Family Welfare; 2011.

12. Fresh Fruit and Vegetable Regulations, C.R.C., c. 285, September 2011. Minister of Justice, Canada.

13. Bangladesh Pure Food Ordinance (Amendment) Act 2005, B. Parliament, Editor. 2005, Bangladesh Parliament Bangladesh Government Press.

14. Food Safety Act, Section 7 P.o.t.U. Kingdom, Editor. 1990, HMSO: London.

15. The Gazette of the Democratic Socialist Republic of Sri Lanka: The Food Act, No. 26 of 1980. 1990, The Ministry of Health: Colombo, Sri Lanka.

16. The Food (First Amendment) Regulation, 2027, D.o.F.T.a.Q. Control, Editor. 1970, Ministry of Agriculture: Nepal Gazette.

17. Giacomini DG. Formal recommendation by the National organic Standard Board (NOSB) to the National Organic Program (NOP). 2012, U.S. Department of Agriculture: USA.

18. Hakim MA, et al. Role of health hazardous ethephon in nutritive values of selected pineapple, banana and tomato. J Food Agric Environ. 2012;10(2):247-51.

19. Soil Association Organic Standards: Food and Drink. 2011, Soil Association. p. 77.

20. Institute EM. EU requirements for fresh fruit and vegetables. BarcelonaSpain; 2007.

21. Bouzayen $M$, et al. Mechanism of fruit ripening. In: Pua EC, Davey MR, editors. Plant developmental biology—biotechnological perspectives. Berlin: Springer; 2010.

22. Kendrick M. The origin of fruit ripening, in Scientific American ${ }^{\mathrm{TM}}$. New York: Nature America Inc; 2009.

23. Prasanna V, Prabha TN, Tharanathan RN. Fruit ripening phenomena-an overview. Crit Rev Food Sci Nutr. 2007;47(1):1-19.

24. Brady CJ. Fruit ripening. Annu Rev Plant Physiol Plant Mol Biol. 1987;38:155-78.

25. Singal $S$, Kumud $M$, Thakral S. Application of apple as ripening agent for banana. Indian J Nat Prod Resour. 2011;3(1):61-4.

26. Lizada C. Mango. In: Seymour GB, Taylor JE, Tucker GA, editors. Biochemistry of fruit ripening. Springer Netherlands; 1993. p. 255-271.

27. Tucker GA, Grierson D. Fruit ripening. In: Davies DD, editor. The biochemistry of plants. New York: Academic Press Inc; 1987. p. 265-319.

28. Beware of these fruits, in The Telegraph Calcutta India. The ABP Publications; 2011. http://www.telegraphindia.com.

29. Theologis A. One rotten apple spoils the whole bushel: the role of ethylene in fruit ripening. Cell. 1992;70(2):181-4.

30. Oetiker JH, SF Yang. The role of ethylene in fruit ripening. In: Postharvest physiology of fruits. ISHS Acta Horticulturae 398: Kyoto, Japan; 1995. p. $167-178$.

31. Le HP. Progress and trends in ink-jet printing technology. J Imaging Sci Technol. 1998;42(1):49-62.

32. Proposed Maximum Residue Limit, Ethephon 2014, Pest Management Regulatory Agency, Health Canada.

33. The Prevention of Food Adultration Act \& Rules 1955, F.S.a.S.A.o.I. (FSSAI), Editor. 1955, Ministry of Health and Family Welfare: India.

34. Prevention of Food Adulteration Rules. 1955, Gazette of India

35. Food Safety and Standards Act, M.O.L.A. Justice, Editor. 2006.

36. A Report Regarding a Proposed Amendment of Certain Sections of the Bangladesh Pure Food Ordinance, 1959 (Ordinance No. LXVIII of 1959), L.C.o. Bangladesh, Editor. 2007, Law Commission of Bangladesh, GoB: Dhaka, Bangladesh. 
37. Mobile Court Act, J.a.P.A. Ministry of Law, Editor. 2009, Legislative and Parliamentary Affairs Division.

38. The West Pakistan Pure Food Ordinance. 1960.

39. Khan MS, Hafeez A. Consumer laws in Pakistan. Islamabad, Pakistan: Consumer Rights Commission of Pakistan; 1999.

40. Islam MN, et al. A legislative aspect of artificial fruit ripening in a developing country like Bangladesh. Chem Eng Res Bull. 2015;18(1):30-7.

41. Islam R. Economic integration in South Asia: charting a legal roadmap. Martinus Nijhoff; 2012

42. Kabir DSH. South Asian Regional Standards Organisation (SARSO). In: South Asia Subregional Economic Cooperation (SASEC) Trade Facilitation Week: Sanitary/Phytosanitaryand Technical Barriers to Trade. 2014, SAARC: Bangkok, Thailand.

43. Saez L. The South Asian Association for Regional Cooperation (SAARC): An emerging collaboration architecture 2011, 2 Park Square, Milton Park, Abingdon, Oxon, OX14 4RN: Routledge.

44. Report on a Workshop on Food Inspection Arrangements in Bangladesh, F.a.A.O.o.t.U. Nations, Editor. 2010, Food and Agriculture Organization of the United Nations: Dhaka, Bangladesh. p. 1-27.

45. Anti-formalin law gets Cabinet's final approval. In: The Independent 2014, Independent Publications Limited. http://www.theindependentbd.com.

46. Cabinet okays Formalin Control Act, 2014. In: Daily Sun. 2014, East West Media Group Limited. http://www.daily-sun.com/.

47. Shen W, Urquhart R. Inkjet ink and paper Interaction. In: Australian Printer. 2004

48. Plant Quarantine Act. 2011. Bangladesh Government

49. Consumer Rights Protection Act 2009, B. Parlliament, Editor. 2009, Bangladesh Parliament: Bangladesh Government Press.

50. The Penal Code, M.o.L.J.a.P. Affairs, Editor. 1860, Legislative and Parliamentary Affairs Division.

51. Food Act 1983. The commissioner of law revision, Malaysia; 2006.

52. Ismail R. Food and Consumer Protection: A case study on Food legislation of Selected Countries. In: Working Paper Series No. 017. 2011, Universiti Kebangsaan Malaysia, Asian Law Institute, NUS: National University of Singapore.

53. Act of The Republic of Indonesia No. 7 of 1996 on Food. 1996, State Gazette of the Republic of Indonesia of 1996 Number 99.

54. Food Safety Law of the People's Republic of China. 2015, Standing Committee of the 12th National People's Congress.

55. Yang Y. Food Safety Laws and Regulations in China, In: A China environmental health project fact sheet. USAID; 2011.

56. Fresh Fruits \& Vegetables Middle East. 2015, International trade centre UN, WTO

57. Gulf Cooperation Council (GCC) in Encyclopædia Britannica. 2014

58. Taha M. United Arab Emirates food and agricultural import regulations and standards narrative. 2013, FAIRS Country Report.

59. Bassiouni H. GCC food standards in 2014. 2015. http://GCCFoodstandard$\sin 2014 . h t m l$
60. Taha M. Qatar food and agricultural import regulations and standardsnarrative. 2011, FAIRS Country Report.

61. Roselan NHBM. Comparison of nutritional content of carica papaya sp by ripening agents. In: Faculty of applied science. University Technology MARA Selangor; 2010. p. 24.

62. WHO, Food Safety and Nutrition Food Law Guidelines. 2005.

63. Catalogue of East African Standards, E.A.C. SECRETARIAT, Editor. 2010.

64. FAO Regional Office for Africa, A., Ghana, National food safety systems In Africa—a situation analysis. In: FAO/WHO Regional Conference on Food Safety for Africa. 2005, FAO/WHO: Harare, Zimbabwe.

65. Africa FWCCF. Comments and information on national food control systems, consumer participation in food standards setting and the use of codex standards at the national level (replies to CL 2014/29-AFRICA). In: CA Commission, editor. Joint FAO/who food standards programme; 2015, FAO/WHO: Yaoundé, Cameroon.

66. Ifenkwe GE. Food safety regulations: reducing the risk of foodborne diseases in rural communities of Abia state, Nigeria. Agric Sci Res J. 2012;2(7):384-9.

67. Africa FWRCoFSf. National food safety systems in Africa-a situation analysis. 2005.

68. Akanya JN. Activities of Standards Organisation of Nigeria. In: XVII IMEKO World Congress. 2003: Dubrovnik, Croatia.

69. WHO/FAO. List of standards. CODEX ALIMENTARIUS, International Food Standards 2015 3/3/2015 [cited 2015 21/4/2015]. http://www.codexalimentarius.org/standards/list-of-standards/en/?provide=standards\&order Field $=$ fullReference\&sort $=$ asc\&num $1=C A C / R C P$.

70. Babangida GIB. Consumer protection council act, Chapter C25, F.o. Nigeria, Editor. 1992.

71. R.E.D. FACTS, Ethylene. 1992, United States Environmental Protection Agency: Office of Prevention, Pesticides And Toxic Substances.

72. The 2013 European Union report on pesticide residues in food 2015, European Food Safety Authority (EFSA).

73. Council Regulation (EC) No. 1234/2007, C.m. organization, Editor. 2013.

74. FAO, IFOAM, UNCTD, Asia Regional Organic Standard. 2012, United Nations Conference on Trade and Development (UNCTAD), Food and Agriculture Organization of the United Nations (FAO) and International Federation of Organic Agriculture Movements (IFOAM).

75. Annual Agriculture Statistics BBOS. Agriculture Wing, Editor. 2007.

76. Board NH. Technical standards and protocol for the fruit ripening chamber in India. 2011, Cold Chain Development Cell.

77. Impianti M. Computerised banana ripening rooms, net price list, M.I. S.r.t., Editor. 2011: Rome, Italy.

78. Bangladesh and Europe 2012. Dhaka, Bangladesh: European Union. 2012.

79. Board NH. Technical standards and protocol for the fruit ripening chamber in India. 2011, Cold Chain Development Cell.

\section{Submit your next manuscript to BioMed Central and we will help you at every step:}

- We accept pre-submission inquiries

- Our selector tool helps you to find the most relevant journal

- We provide round the clock customer support

- Convenient online submission

- Thorough peer review

- Inclusion in PubMed and all major indexing services

- Maximum visibility for your research

Submit your manuscript at www.biomedcentral.com/submit
BioMed Central 